Pak. j. sci. ind. res. Ser. A: phys. sci. 201558 (1) 46-50

\title{
Characterisation and Identification of Taraxerol and Taraxer-14-en-3-one from Jatropha tanjorensis (Ellis and Saroja) Leaves
}

\author{
Sunday Olusegun Oladoye*, Ezekiel Temidayo Ayodele, Misbaudeen Abdul-Hammed \\ and Olajumoke Tolulope Idowu \\ Department of Pure and Applied Chemistry, Ladoke Akintola University of Technology, \\ P.M.B. 4000, Ogbomoso, Oyo State, Nigeria \\ (received September 3, 2013; revised January 31, 2014; accepted February 12, 2014)
}

\begin{abstract}
Jatropha tanjorensis leaves were collected, air dried and pulverised. The pulverised sample was extracted with solvents ( $n$-hexane, ethylacetate and ethanol) of varying polarity to obtain the crude extracts. Repeated column and thin layer chromatographic separation of the crude extracts afforded two compounds which were characterised by their IR, MS, ${ }^{1} \mathrm{H}$ and ${ }^{13} \mathrm{C}-\mathrm{NMR}$ spectral data. Comparison of the data with literature confirmed the compounds to be taraxerol and taraxer-14-en-3-one.
\end{abstract}

Keywords: Jatropha tanjorensis, taraxerol, taraxer-14-en-3-one, chromatography

\section{Introduction}

Jatropha tanjorensis is a plant in the Euphorbiaceae family. It is a perennial herb which is a hybrid specie with phenotypic character between Jatropha curcas and Jatropha gossypifolia (Prabakan and Sujatha, 1999). The plant is widely cultivated in Nigeria primarily for fencing, as a source of leafy vegetable and for medicinal purpose (Oboh and Masodje, 2009; O'Hara et al., 1998).

The leaf extract of the plant is employed traditionally in the treatment of anaemia, diabetes and cardiovascular diseases (Iwalewa et al., 2005; Olayiwola et al., 2004). Studies have been carried out to validate these claims of the traditional uses. The leaf extract has been shown to have hypoglycaemic properties (Olayiwola et al., 2004).

The antioxidant potential of the plant leaf has also been a subject of several studies (Atansuyi et al., 2012; Omobuwajo et al., 2011; Omoregie and Osagie, 2011) and all these studies confirmed the antioxidant properties of this plant. Toxicity studies have also been carried out on the leaf extract of J. tanjorensis with animal models, to ascertain its safety while, some of the studies suggest that it may not be safe (Oyewole et al., 2012; Ogoruvwe and Kori-Siakpere, 2012; Igbinaduwa et al., 2011; Akhigbe et al., 2009). Others suggested, it is safe for human consumption (Omobuwajo et al., 2011; Orhue et al., 2008).

*Author for correspondence; E-mail: oluoladoye@yahoo.co.uk
The antimicrobial potential of this plant has also been evaluated in several studies (Arun et al., 2012; Viswanathan et al., 2012; Sekaran, 1998) and the results showed excellent broad spectrum antimicrobial activity against the tested organisms.

Phytochemical analysis of the leaf extract revealed the presence of saponins, cardiac glycosides, flavonoids, terpenoids and tannins (Oyewole and Akingbala, 2011). However, except for the recent work of Viswanathan et al. (2012) who reported the isolation of friedelin, $\beta$-amyrin, stigmasterol and $\mathrm{R}(+)$-4-hydroxyl-2-pyrrolidinone from the leaf extract of $J$. tanjorensis, there has been no other report in the literature on isolation and characterisation of the phytochemical constituents of this plant. Hence, this study was taken for isolation and characterisation of two terpenoid compounds, taraxerol and taraxer-14-en-3-one, from this plant.

\section{Materials and Methods}

Plant material. Fresh leaves of J. tanjorensis were collected in the month of April 2012 from Ladoke Akintola University of Technology (LAUTECH.), Ogbomoso, Nigeria. Identification was done in the Department of Pure and Applied Biology, LAUTECH. Harvesting was done with hands properly protected with glove to avoid contact with the milky sap of the plant which causes irritation and itching on contact with the skin. 
Sample preparation. The leaves were air dried at room temperature for about two months. Thereafter, the dried leaves were pulverised.

Extraction and isolation. Pulverised sample $755 \mathrm{~g}$ was successively extracted with three solvents of varying polarity ( $n$-hexane, ethylacetate and methanol), at room temperature (Taylor et al., 1983).

The crude $n$-hexane extract (13 g) was subjected to silica gel column chromatography and the column eluted with either one or a mixture of two of $n$-hexane, ethylacetate and methanol. Elution was done by gradually increasing the polarity of the solvent system starting with $100 \%$ $n$-hexane. The eluents were collected in fractions of $200 \mathrm{~mL}$ each. A total of 50 fractions were collected and analysed by thin layer chromatography, fractions with similar TLC profile were pooled together and concentrated to dryness in vacuo. Rechromatography of fraction 21 gave compound 1 (100 mg) as a white crystalline solid.

Fractions 24 to 29 were combined and rechromatographed using the solvent system as stated above and fractions collected at $15 \mathrm{~mL}$ interval, compound 2 (65 mg) crystallised out of fraction 10 of this column.

Melting points were determined on a Kofler apparatus and are uncorrected. IR spectra were recorded by using a Thermo Nicolet 5700 FT-IR spectrometer, in $\mathrm{CHCl}_{3}$. ${ }^{1} \mathrm{H}$ and ${ }^{13} \mathrm{C}$ NMR spectra were recorded in $\mathrm{CDCl}_{3}$ on an Agilent DD2 $400 \mathrm{NMR}$ spectrometer at $400 \mathrm{MHz}$ and $100 \mathrm{MHz}$, respectively. The chemical shifts as $\delta$-values are reported in parts per million ( $\mathrm{ppm}$ ) relative to teteramethylsilane (TMS, $\delta=0$ ) as internal standard.

The positive and negative ion high resolution ESI mass spectra were obtained from a Bruker Apex III Fourier transform ion cyclotron resonance (FT-ICR) mass spectrometer (Bruker Daltonics, Billerica, USA) equipped with an infinity cell, a 7.0 Tesla superconducting magnet (Bruker, Karlsruhe, Germany), an RF-only hexapole ion guide and an external electrospray ion source (Agilent, off axis spray). Nitrogen was used as drying gas at $150{ }^{\circ} \mathrm{C}$. The sample solutions were introduced continuously via a syringe pump with a flow rate of $120 \mu \mathrm{L} / \mathrm{h}$. The data were acquired with $512 \mathrm{k}$ data points; zero filled to $2048 \mathrm{k}$ by averaging 16 scans and evaluated using the Bruker XMASS software (Version 7.0.8).

The electrospray (ESI) mass spectra were performed on a SCIEX API-3200 instrument (Applied Biosystems,
Concord, Ontario, Canada) combined with a HTC-XT autosampler (CTC Analytics, Zwingen, Switzerland). The samples were introduced via auto sampler and loop injection. All solvents used for extraction and column chromatography were General Purpose Reagent (GPR), redistilled before use. Column chromatography was carried out on Merck Si gel 60, while thin layer chromatography (TLC) were done with aluminium sheet pre coated with normal phase silica gel 60 F254 (Merck, $0.20 \mathrm{~mm}$ thickness). The TLC was run using suitable solvent systems. Spots were located on the developed TLC plates by visualisation under ultraviolet light at 254 and $366 \mathrm{~nm}$.

\section{Results and Discussion}

There are few reports on the isolation and characterisation of the phytochemical constituents of J. tanjorensis, however, a recent study reported the isolation of friedelin, B-amyrin, stigmasterol and R-(+)-4-hydroxyl-2-pyrrolidinone from the leaf extract of the plant (Viswanathan et al., 2012). These phytoconstituents present in the methanol extract were suggested to be responsible for the broad spectrum antimicrobial activity of the plant. Now, two compounds are isolated and reported in this work.

The infra red spectrum of compound 1 (Fig. 1) (m.p $238-240{ }^{\circ} \mathrm{C}$ ) revealed absorptions at $3048.7 \mathrm{~cm}^{-1}$ and $3007.7 \mathrm{~cm}^{-1}$ due to $=\mathrm{C}-\mathrm{H}$ of alkene, $2956.7,2913.8$ and $2847.9 \mathrm{~cm}^{-1}$ due to $\mathrm{C}-\mathrm{H}$ stretch of alkane; $1706 \mathrm{~cm}^{-1}$ due $\mathrm{C}=\mathrm{O}$ strectching vibration and at 1471, 1461 and $1447 \mathrm{~cm}^{-1}$ as a result of the bending vibrations of $=\mathrm{C}-\mathrm{H}$. The ESI MS of the compound gave its molecular mass as 424 corresponding to the molecular formula $\mathrm{C}_{30} \mathrm{H}_{48} \mathrm{O}$. The mass spectrum of the compound showed intense peaks at $\mathrm{m} / \mathrm{z} 300,285$ and 204 . Table 1 showing the ${ }^{1} \mathrm{H}$

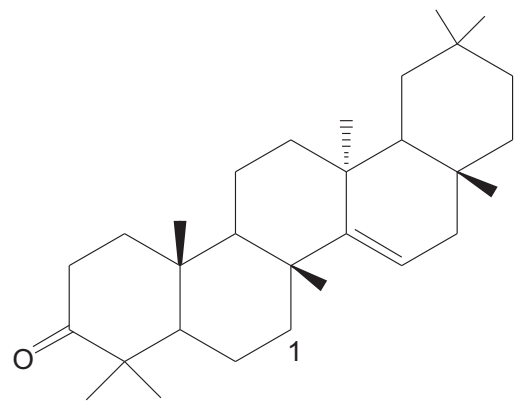

Fig. 1. Structure of Taraxer-14-en-3-one. 
Table 1. ${ }^{1} \mathrm{H}$ and ${ }^{13} \mathrm{C}$ NMR data for compound 1

\begin{tabular}{llll}
\hline \hline Position & $\delta \mathrm{C}(\mathrm{ppm})$ & $\mathrm{C}$ type & $\delta \mathrm{H}(\mathrm{ppm})$ \\
\hline 1 & 38.3 & $\mathrm{CH}_{2}$ & $1.90 ; 1.60$ \\
2 & 34.1 & $\mathrm{CH}_{2}$ & $2.60 ; 2.36$ \\
3 & 217.5 & $\mathrm{C}=\mathrm{O}$ & - \\
4 & 47.6 & $\mathrm{C}$ & - \\
5 & 55.8 & $\mathrm{CH}$ & 1.90 \\
6 & 19.9 & $\mathrm{CH}_{2}$ & $1.75 ; 1.60$ \\
7 & 35.1 & $\mathrm{CH}_{2}$ & $1.70 ; 1.60$ \\
8 & 38.9 & $\mathrm{C}$ & - \\
9 & 48.7 & $\mathrm{CH}$ & 1.70 \\
10 & 35.8 & $\mathrm{C}$ & - \\
11 & 17.4 & $\mathrm{CH}_{2}$ & $1.70 ; 1.60$ \\
12 & 37.68 & $\mathrm{CH}_{2}$ & $1.70 ; 1.60$ \\
13 & 37.72 & $\mathrm{C}$ & - \\
14 & 157.6 & $\mathrm{C}=^{2}$ & - \\
15 & 117.2 & $\mathrm{HC}==$ & 5.57 \\
16 & 36.6 & $\mathrm{CH}_{2}$ & $2.10 ; 1.85$ \\
17 & 37.5 & $\mathrm{C}^{2}$ & - \\
18 & 48.8 & $\mathrm{CH}$ & 1.70 \\
19 & 40.6 & $\mathrm{CH}_{2}$ & $1.70 ; 1.50$ \\
20 & 28.8 & $\mathrm{C}$ & - \\
21 & 33.6 & $\mathrm{CH}_{2}$ & $1.75 ; 1.60$ \\
22 & 33.1 & $\mathrm{CH}_{2}$ & $1.75 ; 1.60$ \\
23 & 26.1 & $\mathrm{CH}_{3}$ & 0.99 \\
24 & 21.5 & $\mathrm{CH}_{3}$ & 0.99 \\
25 & 14.8 & $\mathrm{CH}_{3}$ & 1.03 \\
26 & 29.9 & $\mathrm{CH}_{3}$ & 1.14 \\
27 & 25.6 & $\mathrm{CH}_{3}$ & 1.14 \\
28 & 29.8 & $\mathrm{CH}_{3}$ & 1.03 \\
29 & 33.3 & $\mathrm{CH}_{3}$ & 0.83 \\
30 & 21.3 & $\mathrm{CH}_{3}$ & 0.83 \\
\hline \hline
\end{tabular}

and ${ }^{13} \mathrm{C}$-NMR spectra data for compound 1 , the ${ }^{1} \mathrm{H}$ NMR spectrum shows a double doublet of an olefinic proton at $\delta 5.57 \mathrm{ppm}$ among other signals confirming the olefinic double bond while the ${ }^{13} \mathrm{C}$-NMR confirms a total of thirty carbon atoms, eight of which are methyl carbons, ten methylene carbons, four methine carbons and eight quartenary carbons including carbonyl at $\delta 217.5 \mathrm{ppm}$ and the unsaturated carbon atoms at $\delta 157.6$ and $117.2 \mathrm{ppm}$.

The Infra red spectra of compound 2 (Fig. 2) (M.pt $277-280^{\circ} \mathrm{C}$ ) revealed, among others, a broad absorption band centred at $3843.0 \mathrm{~cm}^{-1}$ due to O-H stretching vibration, absorptions at $3052.6 \mathrm{~cm}^{-1}$ due to $=\mathrm{C}-\mathrm{H}$ stretching vibration, absorptions at 2914.0 and $2848.0 \mathrm{~cm}^{-1}$ due to $\mathrm{C}-\mathrm{H}$ stretching vibration of alkanes and at $1641 \mathrm{~cm}^{-1}$ due to $\mathrm{C}=\mathrm{C}$ stretching vibrations. The ESI MS of the compound gave a molecular mass of 426 corresponding

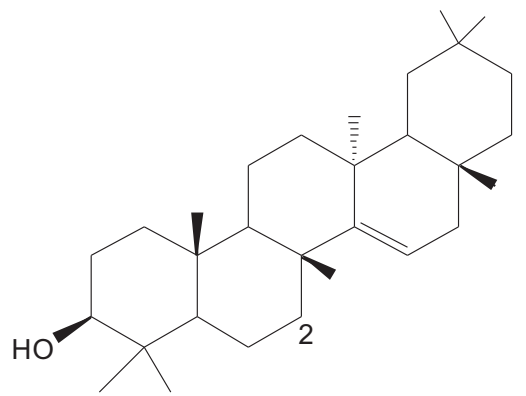

Fig. 2. Structure of Taraxerol.

Table 2. ${ }^{1} \mathrm{H}$ and ${ }^{13} \mathrm{C}$ NMR data for compound 2

\begin{tabular}{llll}
\hline \hline Position & $\delta \mathrm{C}(\mathrm{ppm})$ & $\mathrm{C}$ type & $\delta \mathrm{H}(\mathrm{ppm})$ \\
\hline 1 & 37.7 & $\mathrm{CH}_{2}$ & $1.60 ; 1.15$ \\
2 & 27.2 & $\mathrm{CH}_{2}$ & $1.60 ; 1.40$ \\
3 & 79.1 & $\mathrm{C}-\mathrm{OH}$ & $3.2,3.6$ \\
4 & $39.0 \mathrm{~s}$ & $\mathrm{C}$ & - \\
5 & 55.5 & $\mathrm{CH}$ & 1.40 \\
6 & 18.8 & $\mathrm{CH}_{2}$ & $1.60 ; 1.15$ \\
7 & 35.1 & $\mathrm{CH}_{2}$ & $1.95 ; 1.60$ \\
8 & 38.8 & $\mathrm{C}$ & - \\
9 & 48.8 & $\mathrm{CH}$ & 1.40 \\
10 & 35.8 & $\mathrm{C}$ & - \\
11 & 17.5 & $\mathrm{CH}_{2}$ & 1.15 \\
12 & 37.7 & $\mathrm{CH}_{2}$ & 1.15 \\
13 & 37.6 & $\mathrm{C}$ & - \\
14 & 158.1 & $\mathrm{C}=^{2}$ & - \\
15 & 116.9 & $\mathrm{HC}=^{2}$ & 5.5 \\
16 & 36.7 & $\mathrm{CH}_{2}$ & $2.01 ; 1.95$ \\
17 & 38.0 & $\mathrm{C}$ & - \\
18 & 49.3 & $\mathrm{CH}$ & 1.40 \\
19 & 41.3 & $\mathrm{CH}_{2}$ & 1.15 \\
20 & 28.8 & $\mathrm{C}$ & - \\
21 & 33.7 & $\mathrm{CH}_{2}$ & 1.15 \\
22 & 33.1 & $\mathrm{CH}_{2}$ & 1.15 \\
23 & 28.0 & $\mathrm{CH}_{3}$ & 0.82 \\
24 & 15.44 & $\mathrm{CH}_{3}$ & 0.82 \\
25 & 15.4 & $\mathrm{CH}_{3}$ & 0.99 \\
26 & 29.9 & $\mathrm{CH}_{3}$ & 1.10 \\
27 & 25.9 & $\mathrm{CH}_{3}$ & 1.10 \\
28 & 29.8 & $\mathrm{CH}_{3}$ & 0.99 \\
29 & 33.3 & $\mathrm{CH}_{3}$ & 0.82 \\
30 & 21.3 & $\mathrm{CH}_{3}$ & 0.82 \\
\hline \hline
\end{tabular}


to a molecular formula of $\mathrm{C}_{30} \mathrm{H}_{50} \mathrm{O}$. The mass spectrum of the compound also showed intense peaks at $\mathrm{m} / \mathrm{z} 302$ and 204. The ${ }^{1} \mathrm{H}$ NMR of compound 2 confirmed the presence of $\mathrm{OH}$ group in the compound through the double doublet centred at $\delta 3.20 \mathrm{ppm}$, the methylene group is also confirmed through the double doublet at $\delta 5.50 \mathrm{ppm}$. The ${ }^{13} \mathrm{C}$ NMR spectrum revealed a total of thirty carbon atoms distributed as follows: 8 methyl, 10 methylene, 5 methine and 7 quartenary carbons as presented in Table 2. The spectra characteristics of these compounds confirm compound 1 to be taraxer-14-en3-one while compound 2 as taraxerol. These interpretations are in excellent agreement with the literature data for these compounds isolated and characterised from Myrica rubra and Euphorbia pubescens (Valente et al., 2004; Sakurai et al., 1987).

\section{Acknowledgement}

The support of Ladoke Akintola University of Technology, Ogbomoso, Nigeria through Senate Research Grant is appreciated. The Authors are also grateful to Prof. Dr. Ludger Wessjohann and Dr. Katrin Franke of Leibnitz Institute of Plant Biochemistry, Halle- Saale, Germany for measurement of the spectroscopic data of the compounds.

\section{References}

Akhigbe, A.O., Idu, M., Orhue, E.S., Ataman, J.E., Ehimwenman, S.O. 2009. Effect of Jatropha tanjorensis J.I. Ellis and Soroja leaves in rabbits: Biochemistry and ultrasonography. Research Journal of Medicinal Plant, 3: 29-33.

Arun, K.P., Ravichandran, N., Vajrai, R., Brindha, P. 2012. Studies on micromorphological standardization, antimicrobial efficacy and nutritional values of Jatropha tanjorensis. International Journal of Pharmacy and Pharmaceutical Sciences, 4: 139142.

Atansuyi, K., Ibukun, E.O., Ogunmoyole, T. 2012. Antioxidant properties of free and bound phenolic extract of the leaves of Jatropha tanjorensis in vitro. Journal of Medicinal plants Research, 6: 4667-4674.

Igbinaduwa, P.O., Usifoh, C.O., Ugwu C.C. 2011. Phytochemical analysis and toxicological evaluation of the methanolic extract of Jatropha tanjorensis leaf. Journal of Pharmacy \& Bioresources, 8: 86-91.
Iwalewa, E.O., Adewunmi, C.O., Omisore, N.O.A., Adebanji, O.A., Azike, C.K., Adigun, A.O., Olowoyo, O.G. 2005. Pro- and antioxidant effects and cytoprotective potentials of nine edible vegetables in South West. Journal of Medicinal Food, 8: $539-544$.

O’Hara, M.D., Kiefer, K., Farrell, T., Kemper, K. 1998. A review of twelve commonly used medicinal herbs. Archives of Family Medicine, 7: 523-536.

Oboh, F.O.J., Masodje, H.I. 2009. Nutritional and antimicrobial properties of Jatropha tanjorensis leaves. American-Eurasian Journal of Scientific Research, 4: 7-10.

Ogoruvwe, O.J., Kori-Siakpere, O. 2012. Alterations in the activities of the nitrogenous waste of Clarias Gariepinus after intramuscular injection with aqueous extracts of Jatropha tanjorensis leaves. Journal of Pharmacy and Biological Sciences, 2: 35-38.

Olayiwola, G., Iwalewa, E.O., Omobuwajo, O.R., Adeniyi, A.A., Verspohl, E.J. 2004. The antidiabetic potential of Jatropha tanjorensis leaves. Nigerian Journal of Natural Products and Medicine, 8: $55-58$.

Omobuwajo, O.R., Alade, G.O., Akanmu, M.A., Obuotor, E.M., Osasan, S.A. 2011. Microscopic and toxicity studies on the leaves of Jatropha tanjorensis. African Journal of Pharmacy and Pharmacology, 5: $12-17$

Omoregie, E.S., Osagie, A.U. 2011. Effect of Jatropha tanjorensis leaves supplement on the activities of some antioxidant enzymes, vitamins and lipid peroxidation in rats. Journal of Food Biochemistry, 2: 409-424.

Orhue, E.S., Idu, M., Ataman, J.E., Ebite, L.E. 2008. Haematological and histopathological studies of Jatropha tanjorensis (Ellis and Soroja) leaves in rabbits. Asian Journal of Biological Sciences, 1: 84-89.

Oyewole, O.I., Oladipupo, O.T., Atoyebi, B.V. 2012. Assessment of renal and hepatic functions in rats administered methanolic leaf extract of Jatropha tanjorensis. Annals of Biological Research, 3: $837-$ 841.

Oyewole, O.I., Akingbala, P.F. 2011. Phytochemical analysis and hypolipidemic properties of Jatropha tanjorensis leaf extract. European Journal of Medicinal Plants, 1: 180-185. 
Prabakan, A.J., Sujatha, M. 1999. Jatropha tanjorensis, Ellis and Soroja, a natural interspecific hybrid occurring in Tamil Nadu, India. Genetic Resources and Crop Evolution, 46: 213-218.

Sakurai, N., Yaguchi, Y., Inoue, T. 1987. Triterpenoids from Myrica rubra. Phytochemistry, 26: 217-219.

Sekaran, R. 1998. Antimicrobial action of the leaf extract of Jatropha tanjorensis. Ancient Science of Life, 18: $50-51$.

Taylor, M.D., Smith III, A.B., Furst, G.T., Gunasekara, S.P., Bevelle, C.A., Cordell, G.A., Farnsworth, N.R., Kupchan, S.M., Uchida, H., Branfman, A.R., Dailey Jr., R.G., Sneden, A.T. 1983. New anti-leukemic
Jatrophone derivatives from Jatropha gossypiifolia: Structural and stereochemical assignment through nuclear magnetic resonance spectroscopy. Journal of American Chemical Society, 105: 3177-3183.

Valente, C., Pedro, M., Duarte, A., Nascimento, M.S.J., Abreu, P.M., Ferreira, M.J.U. 2004. Bioactive diterpenoids: A new jatrophane and two ent-abietanes, and other constituents from Euphorbia pubescens. Journal of Natural Products, 67: 902-904.

Viswanathan, M.B., Jeya Ananthi, J.D., Sathish-Kumar, P. 2012. Antimicrobial activity of bioactive compounds and leaf extracts in Jatropha tanjorensis. Fitoterapia, 83: 1153-1159. 